慶應義塾大学学術情報リポジトリ

Keio Associated Repository of Academic resouces

\begin{tabular}{|c|l|}
\hline Title & A reticuloendothelial system-activating glycan from the seeds of malva verticillata \\
\hline Sub Title & \\
\hline Author & $\begin{array}{l}\text { 友田, 正司(Tomoda, Masashi) } \\
\text { 金成, 美枝子(Kanari, Mieko) } \\
\text { 権田, 良子(Gonda, Ryoko) } \\
\text { 清水, 訓子(Shimizu, Noriko) }\end{array}$ \\
\hline Publisher & 共立薬科大学 \\
\hline Publication year & 1989 \\
\hline Jtitle & $\begin{array}{l}\text { 共立薬科大学研究年報 (The annual report of the Kyoritsu College of } \\
\text { Pharmacy). No.34 (1989.) ,p.59- 59 }\end{array}$ \\
\hline JaLC DOI & \\
\hline Abstract & \\
\hline Notes & 抄録 \\
\hline Genre & Technical Report \\
\hline URL & https://koara.lib.keio.ac.jp/xoonips/modules/xoonips/detail.php?koara_id=AN00062898-0000003 \\
4-0059
\end{tabular}

慶應義塾大学学術情報リポジトリ(KOARA)に掲載されているコンテンツの著作権は、それぞれの著作者、学会または出版社/発行者に帰属し、その権利は著作権法によって 保護されています。引用にあたっては、著作権法を遵守してご利用ください。

The copyrights of content available on the KeiO Associated Repository of Academic resources (KOARA) belong to the respective authors, academic societies, or publishers/issuers, and these rights are protected by the Japanese Copyright Act. When quoting the content, please follow the Japanese copyright act. 


\title{
A Reticuloendothelial System-Activating Glycan from the Seeds of Malva verticillata*
}

\author{
Masashi Tomoda, Mieko Kanari, Ryőko Gonda and Noriko Shimizu \\ 友田正司，金成美枝子，権田良子，清水訓子
}

From the hot water extract of the seeds of Malva verticillata, a polysaccharide, designated as MVS-IIIA, has been isolated by fractionation on DEAE-Sephadex A-25 (carbonate) followed by gel chromatography on Sephacryl S-500 and affinity chromatography on Con A-Sepharose columns. The polysaccharide gave a single band on PAGE and gave a single peak on gel chromatography.

MVS-IIIA is composed of L-arabinose : D-xylose : D-galactose : D-galacturonic acid in the molar ratio of $16: 1: 8: 3$, and it contains a peptide moiety (1.7\%). Its value of molecular mass was estimated to be about $8.5 \times 10^{6}$.

The results of methylation analysis of the original polysaccharide and the carboxyl-reduced derivative and ${ }^{13} \mathrm{C}-\mathrm{NMR}$ spectrum suggested that the minimal unit of the polysaccharide is composed of four terminal $\alpha$-L-arabinofuranose, ten $\alpha-1,5$-linked L-arabinofuranose, two $\alpha$-1,3-linked L-arabinopyranose, one $\beta$-1,4-linked $D$ xylopyranose, four $\beta$-1,3-linked D-galactopyranose, four 3,6 -branched $\beta$-Dgalactopyranose and $\alpha-1,4$-linked $D$-galacturonan residues. The periodate oxidation studies also supported these conclusions.

The effect of MVS-IIIA on a RES was demonstrated by the in vivo carbon clearance test. When administered i.p. $(50 \mathrm{mg} / \mathrm{kg})$, the phagocytic index of MVS-IIIA was $0.4492 \pm 0.1048$. Thus the value was quite remarkably increased, suggesting powerful activation of RES by i.p. injection of MVS-IIIA.

The structural characterization of MVS-IIIA is both its high arabinose content and the presence of $\alpha-1,3$-linked L-arabinopyranose residues. Most of the RES-activating polysaccharides from Oriental crude drugs contain arabino-3,6-branched galactan units in common as their major parts, though they have different types of backbone chain.

* 本報告は Phytochemistry 28, 2609 2611（1989）に発表。 